JEASP

Journal of English for Academic and Specific Purposes

Volume 2 Number 1, June, 2019

\title{
ENGAGING NON-ENGLISH DEPARTMENT STUDENTS TO SPEAK: A CHALLENGING PATH
}

\author{
Fitria Muji Pratawati \\ (fitria.pratawati@gmail.com)
}

Pusat Pengembangan Bahasa inggris

Universitas Negeri Maulana Malik Ibrahim Malang

\begin{tabular}{|c|c|}
\hline ARTICLE & ABSTRACT \\
\hline Keywords: & This study aimed at sharing how the teacher initiates their students to speak. All \\
\hline Speaking, & $\begin{array}{l}\text { efforts have been done in class in order to keep the class alive and students were } \\
\text { active in joining the lesson. The students were from non-English department who }\end{array}$ \\
\hline ESP students, & $\begin{array}{l}\text { studied ESP. They were from different major but still in one generation of the } \\
\text { State Universities in Malang, East Java-Indonesia. This created the point of view }\end{array}$ \\
\hline engaging activities, & $\begin{array}{l}\text { that some students tend to take this course only as the requirement to fulfill their } \\
\text { credits in two semesters. Therefore, the role of English teacher dealing with }\end{array}$ \\
\hline debate, & $\begin{array}{l}\text { boosting students' speaking awareness is very pivotal. The result were students } \\
\text { tended to be more actively engaged in the class joining the activities given to }\end{array}$ \\
\hline video & $\begin{array}{l}\text { them, such as debate and making video related their major. Then, this study } \\
\text { suggests the teaching practitioners always considering the good atmosphere given } \\
\text { to the students before the lesson begins. So, this will be the initial part of making } \\
\text { them comfort in class and try to have teamwork with them to succeed the } \\
\text { objective of the class. }\end{array}$ \\
\hline
\end{tabular}

\section{INTRODUCTION}

Dealing with the case of the non-English department students in English classes, it may become one of the tiring attempts to do. Actually, the students come with their various English proficiencies and gather into one in the class. This moment pushes the teacher to think twice how to encourage them to speak, even in small portion. What has been spoken or told in English by students in the class becomes one of the starting points the teacher can lead.

I was conducting the study in the class in one semester where the students are majoring in non-English department. They got ESP class in one year, in the third and fourth semester. This case encouraged me to know how non-English department students can be motivated to speak. At that time, I observed the intensive classes or I can say that they were afternoon classes. They were intended to improve their speaking ability in the class. I did believe that not all the students assume that speaking in English is easy for them. Some of them really did not think so. At the beginning of the 


\section{JEASP}

Journal of English for Academic and Specific Purposes

Volume 2 Number 1, June, 2019

semester, I tried to engage them by having a discussion about our class's rules. I spoke in English, in a very simple structure. With a hope, they would answer me in English as well. In fact, some students were very eager to speak while the rests were not really interested. The students who spoke in English when responding me were always the same students. This time, I realized that it was a burden in their head when I asked them to speak even I had already mentioned that they could do code-mixing and translation in Bahasa Indonesia after speaking. Constantly, they were all almost silent. It seemed that it was difficult for them to recall the words and speak them out.

From that moment, I was aware of something really important that this case challenged me a lot. That is why I started to encourage them to speak by providing some engaging activities such as playing games, having a small debate by providing engaging topic, and making videos related to their major as their final project in the end of the semester. Since one of the important parts of learning a foreign language is practicing in the target language. Cameron in Harmer (2001) speaking is one of the ways to convey the message so the other people can get what the speaker said. In practicing a simple speaking, students are allowed to ignore the grammar that makes them confused to arrange the utterances. The word 'ignore' means that they were allowed to make the sentences without thinking too much in grammar since in the end of the activities, there will be always feedback for them from me. This makes them easy to express their ideas without thinking whether or not their sentences have already been true. The predominant thing in speaking is students are able to express themselves in the target language (Yule, 1983). All the words came out from their mouth were so precious for me as an English lecturer who taught ESP at that time. All in all, the final objective of the semester was students are expected to enhance their speaking ability although they are not from English department.

Widiati \& Cahyono (2006) state that communication is a pivotal part in human life. It becomes an idea conveyance from one to another. Therefore, a lot of things to do by teacher who teaches in a speaking class make the class lively. Suwarsih (2002) states there are many ways that have been done to enhance quality of EFL teaching in Indonesia. There have been some techniques and ways implemented in the class to make students not reluctant to speak. I myself implemented a debate technique using a debatable topic to enhance my students to speak. Krieger (2005) points out that the debate is a great activity to engage students in cognitive and linguistic ways. In debate, students are expected to respond the rival's argument. There is a feeling that each member of group does not want to be a loser in this competition. They enthusiastically defended their group using all the efforts and arguments they found. It seemed that they thought their group was so priceless to be defeated. So, they need to totally support their arguments using their limited speaking ability. This case would challenge them to speak for both the active students and the silent ones. The silent one would be 
asked by the other students to speak. This way was done by some students who felt that they had already given many statement and arguments so that the active students wanted the silent ones to speak alternately.

\section{THE CHARACTERISTICS OF STUDENTS}

The objective of the class is to help the students to speak and express their idea dealing with the activities given in the class. I myself applied the activities in some different classes. They were Informatics Engineering, Primary Teacher Education, and Syariah Banking. Those classes were given to me as my classes in some previous semesters. In this era, they were asked read articles written in English a lot in their major. By reading articles, journals, books and all materials written in English, they were able to get more information to study and share. Dealing with the sharing knowledge, they needed to speak in order to push out what they have in their head. The total of students in each class was different. But, all classes were thirty up to forty students in average. They were in fourth semester taking intensive English class that ran in the afternoon as the requirement of fulfilling the credits. In fact, they took four times of English class during a year. This was called as one-year English program in this university. The first semester was for Regular English 1 and its Intensive class while the second semester was for Regular English 2 and its Intensive class. It means that, in one semester, they experienced four English classes where two of them were in the morning and the other ones were in the afternoon. I actually taught the Intensive classes. The reasons why I applied activities in these classes were I was instructed to teach intensive class and the objective of the course was to enhance students' speaking ability. It was clearly stated that speaking period would be much more available in this course rather than in Regular class. This course was extremely required them to practice speaking more often.

In recording the activities I applied, I provided recorder to record the process in the class while I also was having notes with me to write the feedbacks for students and open-ended questionnaire to ask to some representative students regarding their feeling and their experiences joining the class. Those two instruments were intended to reveal how the activities are able to help the students to raise their motivation to speak in the class. I took one semester to run the activities for students. It had four months. I did not collect them every day. I collect the data when they had a debate in the class and games. When I applied my technique in class, I tried to be a class controller who sat in the middle of the class while writing notes and my recorder to record all the activities. Then, in the end of semester, to make sure their feeling in the class was in line with their responses I distribute the questionnaire to some representative students. 
JEASP

Journal of English for Academic and Specific Purposes

Volume 2 Number 1, June, 2019

The questionnaire used in this study was open-ended style. This would help them to respond easily to the questions since the questions tended to dig the information from the students deeper. There were 5 questions related the topic given to the students. Those five points that have been responded by the students would be clarified to them whether they were really answer that way. This method would give the extra information to this study since some of the students wrote the responses briefly. In contrast, when they were asked to clarify their responses they tended to give more explanation given to this study. They wanted to specifically explain what they want to write. Thus, the responses were absolutely proper to be included in the study.

All responses submitted would be the starting source of the activities. In the beginning of writing this article, I was collecting the data from recording and open-ended questionnaire responded by students. Then, I was filtering the data to choose selectively the supportive data. Then, I finally began to write the activities I applied in my class.

Another important thing in conducting the research was I had to keep the identities of the students' since they were very private and confidential. Therefore, I used a coding system. The names of all the respondents would be shown in acronyms. (FM) is for the researcher. (AA) is for the first respondent, $(\mathrm{BB})$ is for the second respondent, $(\mathrm{CC})$ is for the third respondent, (DD) is for the fourth respondent.

\section{THE DEBATE AND VIDEO MAKING ACTIVITIES}

Dealing with the case of teaching ESP for non-English department students, it would be very meaningful to treat them as motivated learners. I myself did not need to bear in mind that teaching them was very difficult because every student had their own characteristics. As a lecturer, I was aware of teaching English as EFL in this area so I let myself to locate me as students' position.

The first activity I did in the class was asking the students to divide the class into two big groups. The students would experience a debate. As information, a debate I conducted in the class was very simple one since I considered proficiency level of my students and the objective of the class. The most important point in this activity was I could encourage them to speak, to express what they have in mind. The more often they speak the better atmosphere the debate is. I emphasized in the beginning that everyone should speak without exception. This activity allowed the students to have a discussion first within each group.

I gave them several minutes to think about the argument and opinion related to the topic. The topic I gave to them was "Do you really need your Smartphone in your daily life?" The pros group would tend to support this statement while the Cons group would be more likely against it. Their 


\section{JEASP}

Journal of English for Academic and Specific Purposes

Volume 2 Number 1, June, 2019

argument should be based what side they are. The pros group would tent to give the supporting details about the topic and the cons group would tent to reject what the pros group would say. Before starting the debate, I emphasized that the students did not need to worry about their grammar and what tenses they should use. This point is very important to tell them since the anxiety might come from the class atmosphere. I tried to support them to speak by saying "That's okay not to use the grammar properly as long as your interlocutor understands what you are saying". The way to say it to them should be clear as well and it should be said again and again. In this activity, I could see that the eagerness of the students to follow the debate was very wonderful. Sometimes they asked to their friends next to them how to speak and pronounce the word. This happened many times. The active activity was proven by the response from the questionnaire. Her explanation was stated in excerpt 1.

\section{Excerpt 1}

FM : What do you feel when you have to experience a debate activity like this?

AA : Actually, I never have debate before, Miss. In SMA, my school, I did not follow this extracurricular because I am very afraid that I cannot speak. I do not know how to say. But in this activity, I feel free to express my idea although my grammar is not good. I do not feel that I am under pressure.

From the excerpt 1 , we knew that the student was able to express their idea without feeling depressed. She made a very great statement saying that she was comfortable with the situation. In her previous years, she mentioned that she faced the frightening situation in her class. I did not know what happen actually until she said that way. For sure, the class situation and the way to say to the students were so important parts to consider before implementing particular activity. Thus, giving the instruction to the students is one of the pivotal things to consider before doing the action.

When the debate was running, I was the person who helped to clarify what each group wanted to say so that the rival group could understand and then, respond to another group's argument. The role of teacher, in this case, became very crucial to do because some students did not understand what their friends say. In this part, I should clarify and re-ask to that group to make the argument or question easy to understand. Sometimes, the students themselves, with their high English proficiency, wanted to clarify the questions to the giver in order to ask for clarification. The obstacle was when one group gave the question to another group and then they were stuck for an answer. They did not know how to answer since they could not find better responses to the arguments.

Almost all of group members were also enthusiastic to follow the debate even they were not directly raise their voice. Just in a while, they yelled either to support or to laugh at their friends. The class became lively. The students were asked to speak alternately. The most important thing to consider for all the students was they were not allowed to be dominant in the debate. They need to 


\section{JEASP}

Journal of English for Academic and Specific Purposes

Volume 2 Number 1, June, 2019

give a turn to their friends so that all members of each group had an opportunity to express their ideas. If the condition in the middle of debate became very spirited, in this case, the students would be very eager to express their ideas without giving the other students a chance to speak, I myself should be a mediator for all of them. I tried to explain and emphasize the highlight point to be responded and decrease the less point to avoid in this forum.

At the end of debate, I made the conclusions and remarks to end up the activity. After all, it seemed that students were very relieved after joining the debate. It was like forcing something they had from their mind-expressing the ideas out. The pros and the cons group would become partner again after joining this debate. They admitted that this activity would not break their relationship in the class. It was just an activity to enhance their speaking ability without considering much on grammar.

Other activity I gave to the students was to make a video based on their major in the middle of the semester. In improving their speaking ability, I asked them to make a short video of making of scale model for those were from architectural engineering major and making an application for those who were from informatics engineering major. The model I asked to them was the simplest one. They could make scale model, painting, diagram, a game application, a simple dictionary or any application related to their major. Fortunately, they were very spirited in listening my instruction to make one of them. This was an individual final project for each student. One by one, they raised questions to me about the rule and what I would assess. I talked to them that I raised three points that they need to cover in her video. The first one was mentioning the name of the scale model and describing the function and the advantages of it. I was trying to motivate them to speak without thinking too much about grammar and also sentence structure.

The duration to make the video was about one and a half month. I needed to make sure that they have enough time to prepare all the things because they also had the assignments from other lecturers. I offered to them whether they could send me the video to email or directly perform in front of the class. Absolutely, they answered that the best way to show their talent was by making a video. In fact, I did not really think of it. The reasons why they liked to make a video were they know what to say and record. They also had times to edit their video so the final result sent to me would be the best version. The response regarding this activity also came from to the student BB. His explanation was mentioned in the excerpt 2 .

\section{Excerpt 2}

FM : What do you have in your mind when I offer you to choose making a video or performing in the class?

BB : I prefer to make a video Miss. Because I know when I have to record and I can re-edit or re-play my recording if there is a mistake. This will be simple for me since I still need to learn English but I know it is all about my scale model. I just need time to make the sentence. 
From excerpt 2, it was mentioned that by making a video, students were free to take the recording more than once. This case encouraged them to provide the best video to be their final project. The result was amazing. They could submit their assignment on time with very good result. I said this way since all of the students made various applications and scale models like what I asked them to do. They explained in English very well and showed their great scale model. Here is the best version of their final projects. This activity became the final project of this class since the focus in this semester was speaking. I focused on how they deliver the explanation about their scale model rather than their grammar. I did not want to make them confused by only thinking about the English structure. The main point of my assessment was as long as their speech that was clear and acceptable, it was great presentation.

I also put the maximum duration of the video. This rule was so important to be explained to students since it would take times in checking the video if they made a longer one. The duration would not be longer than 7 minutes. I told this rule to keep the video in line with three points I have mentioned to them. In average, they made a video with the duration of 4-7 minutes. The sound of voice which came out from the video should be clear, whatever application they used.

Another excerpt was also delivered by the other student. The explanation was in the excerpt 3 .

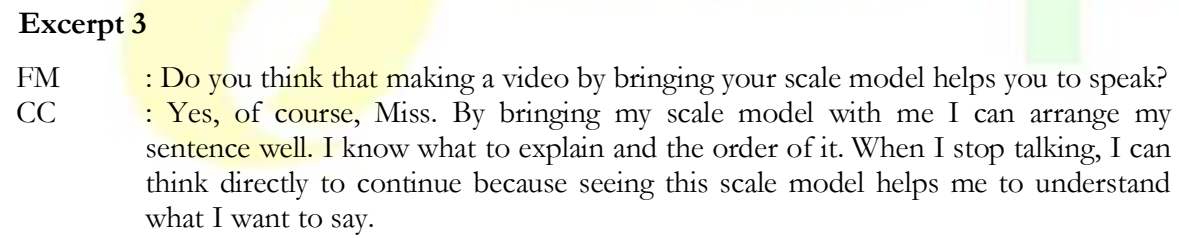
sentence well. I know what to explain and the order of it. When I stop talking, I can think directly to continue because seeing this scale model helps me to understand what I want to say.

Excerpt 4

FM : Do you think that making a video by explaining your application help you to speak?

DD : I do. When I speak without explaining the real application like this, I think I never get the vocabulary to say. I don't know what I should explain here. I have already made the application and this time I try to explain what I have made. I made it by myself so I know what to say and before making the video, I prepare all the things to make sure I know the things I will mention in my video about my application.

From the excerpt 3, we know that the student mentioned her opinion related to the video. She emphasized that by bringing the scale model they could easily speak in order. This case helped her to continuously speak and explain about her scale model. In regard to the major she took, the video was made in a purpose. She was asked to explain the thing she and her friends were familiar with.

While in excerpt 4 , the student says that when he was asked to make an application related to their major and use English in his presentation, he felt that this way could be better alternative to boost his motivation and make his presentation run well since he had already prepared all the things 
before he made the video. So, in the end, he could submit the best version of his video as his final project in my class.

Thus, having debate in class and making video related to students' major could motivate students to speak. They actually did not really need to think about the grammar when they speak. They were just asked to raise their voice under the theme provided. Even the grammar was considered to be the second thing; it did not mean that grammar was not important. I reminded the students to always focus on what they want to say rather than checking their words, tenses or structure they should use.

According to Abukhattala (2015), bringing the technology in the class will meaningfully enhance the teacher's role; the belief and practices influence how they employ the technology in the classroom. This means that there is a great benefit put in the class when the teacher provided the technology for the students. The teaching and learning process would not be very boring as well as Implementing the debate in ESP class was also a good idea since the impact to the students would be marvelous. Alasmari \& Ahmed (2012) say that when debating is employed in the class, all English four skills (e.g. listening, speaking, reading, and writing) are practiced. In addition to that, the debaters were also expected to pronoun the words better and make a logic building to make sure that the arguments delivered correctly. All in all, by joining debate and making video related to their major, students would learn how to create acceptable sentences and built a strong bounding with their friends in class.

\section{CONCLUSION AND SUGGESTION}

In teaching and learning process, there are always ways to do in the class to make the class lively and motivate the students to participate actively. The teacher should become the parameter in the class who controls and monitors all the activity given to the students and see the students' responses. This condition becomes very important since the role of the teacher is to reach the objectives of the class. In addition to this, the ESP class is always special to treat since the students come from non-English department. They need special treatment as well to challenge them to speak in the class. Before asking the students to speak, remember that the teacher should be the role model first so the students can use it as their starting point to begin speaking in the class. Last but not least, a teacher is a candle light for their students. They send a bright light to them. So, being a good model for our students is a must. All in all, this study also suggest to the all-English teaching practitioners to always consider the activity and the atmosphere the given to the students. It means that everything given to the students in the class more or less always put the impact to them. Thus, to make the class enjoyable is strongly recommended in ESP class. 
JEASP

Journal of English for Academic and Specific Purposes

Volume 2 Number 1, June, 2019

\section{REFERENCES}

Abukhattala, I. (2015). The Use of Technology in Language Classroom in Libya. International Journal of Social Science and Humanity, 6(4).

Alasmari, A., \& Ahmed, S. S. (2012). Using Debate in EFL Classes. English Language Teaching Journal, $6(1)$.

Harmer, J. (2007). The Practice of English Language Teaching. UK: Pearson Education Limited.

Krieger, D. (2005). Teaching Debate to ESL Students: A six-Class Unit. The Internet TESL Journal, 11(2).

Suwarsih, M. (2002). Developing Standards for EFL in Indonesia as Part of the EFL Teaching Reform. TEFLIN, 13(2).

Widiati, U., \& Cahyono, B.Y. (2006). The Teaching of EFL Speaking in the Indonesian Context: The State of the Art. BAHASA DAN SENI Journal, 34(2).

Yule, G., \& Brown, G. (1983). Teaching the Spoken Language: An Approach Based on The Analysis of Conversational English. UK: Cambridge University Press. 